\title{
Analisis Penerapan Penguatan Pendidikan Karakter Sebagai Implementasi Kurikulum 2013
}

\author{
Ririn Dwi Novitasari ${ }^{1}$, Arfilia Wijayanti ${ }^{2}$, Filia Prima Artharina $^{3}$ \\ ${ }^{123} J u r u s a n$ Pendidikan Guru Sekolah Dasar \\ Universitas PGRI Semarang \\ Semarang, Indonesia
}

e-mail: ririn2194@gmail.com, Arfilia34@gmail.com, Filiaprima11@gmail.com

\begin{abstract}
Abstrak
Penelitian ini bertujuan untuk mendeskripsikan kesiapan sekolah SD Negeri 1 Pulorejo dalam penerapan penguatan pendidikan karakter sebagai implementasi kurikulum 2013 dalm hal : 1) kesiapan kurikulum sekolah, 2) kesipan pendidik dan tenaga kependidikan. 3) kesiapan peserta didik. Penilitian ini adalah deskripsi kualitatif. untuk mengetahui penerapan penguatan pendidikan karakter sebagai implementasi kurikulum 2013 di SDN 1 Pulorejo. Jenis penelitian ini adalah penelitian kualitatif dengan menggunakan pendekatan deskripsi kualitatif. Tempat yang dipilih dalam penelitian ini adalah SD Negeri 1 Pulorejo. Data dalam penelitian ini diperoleh melalui observasi, angket, wawancara, dan dokumentasi. Hasil analisis menunjukkan bahwa penerapan penguatan pendidikan karakter sebagai implementasi kurikulum 2013 di SDN 1 Pulorejo diketahui bahwa SDN 1 Pulorejo sudah mengimplementasi pendidikan karakter dalam kurikulum 2013. Hasil analisis ini berdasarkan sepuluh prinsip pelaksanaan PPK. Pendidikan karakter disekolahan ini diselenggarakan melalui pendidikan dan pembelajaran untuk dapat mencapai visi yang unggul dalam prestasi, cerdas terampil beriman, bertaqwa, berakhlak mulia, berkarakter bangsa dan berwawasan gender, dan sesuai dengan peraturan presiden No. 87 Tahun 2017 tentang penguatan pendidikan karakter bahwa penyelenggaraan penguatan pendidikan karakter pada satuan pendidikan formal saat ini sangatlah diperlukan, hal ini dikarenakan anak usia sekolah merupakan aset bangsa dalam mewujudkan cita-cita bangsa yang berbudaya dan memiliki semangat kebangsaan, peduli sosial serta cinta tanah air.
\end{abstract}

Kata kunci: implementasi, kegiatan pembiasaan, pendidikan karakter

\begin{abstract}
This study aims to describe the readiness of SDN 1 Pulorejo schools in the application of strengthening character education as the 2013 curriculum implementation in terms of: 1) school curriculum readiness, 2) readiness of educators and education staff. 3) readiness of students. This research is a qualitative description. to find out the application of strengthening of character education as the implementation of the 2013 curriculum at SDN 1 Pulorejo. This type of research is a qualitative study using a qualitative description approach. The place chosen in this study is SDN 1 Pulorejo. The data in this study were obtained through observation, questionnaires, interviews, and documentation. The results of the analysis show that the application of strengthening character education as the implementation of the 2013 curriculum at SDN 1 Pulorejo is known that SDN 1 Pulorejo has implemented character education in the 2013 curriculum. The results of this analysis are based on the ten principles of KDP implementation. Character education at the school is organized through education and learning to be able to achieve a vision that is superior in achievement, intelligent, skilled, faithful, devoted, noble, national character and gender-oriented, and in accordance with Presidential Regulation No. 87 of 2017 concerning strengthening of character education that the implementation of strengthening of character education in formal education units at this time is very necessary, this is because school-age children are the nation's assets in realizing the ideals of a nation that is cultured and has a spirit of nationalism, social care and love for the motherland.
\end{abstract}

Keywords: implementation, habituation activities, character education 


\section{Pendahuluan}

Pelaksanaan pendidikan di Indonesia dengan adanya perubahan zaman menjadi salah satu tolak ukur diperlukannya kualitas pendidikan yang baik agar terciptanya sumber daya manusia yang cerdas. Karena bagaimanapun pendidikan merupakan elemen yang sangat penting dalam kemajuan bangsa, untuk itu jika bangsa ini ingin maju maka pendidikan justru harus dimajukan terlebih dahulu. Sehinggga memunculkan usaha pembangunan kemandirian siswa dalam ranah pendidikan. Pada prinsipnya pendidikan merupakan usaha sadar dan terencana untuk mewujudkan suasana belajar dan proses pembelajaran agar peserta didik secara aktif mengembangkan potensi dirinya untuk memiliki pengendalian diri, kepribadian, kecerdasan, dan keterampialan proses yang diperlukan dalam kehidupan. (Undang-undang sisdiknas nomor 20 tahun 2003). Lebih lanjut mengenai fungsi dan tujuan pendidikan nasional yang terdapat dalam undang-undang sistem pendidikan nasional nomor 20 tahun 2003 menjelaskan bahwa : Pendidikan nasional berfungsi mengembangkan kemampuan dan membentuk watak serta peradaban bangsa yang bermartabat dalam rangka mencerdaskan kehidupan bangsa, bertujuan untuk berkembangnya potensi peserta didik agar menjadi manusia yang beriman dan bertakwa kepada Tuhan Yang Maha Esa, berakhlak mulia, sehat, berilmu, cakap, kreatif, mandiri, dan menjadi warga negara yang demokratis serta bertanggung jawab. Fungsi dan tujuan pendidikan nasional di atas merupakan usaha membentuk individu yang mandiri, utamanya membangun kemandirian siswa dalam belajar. Kemandirian belajar telah menjadi salah satu aspek sikap dalam pendidikan karakter. Lebih khusus mengenai sikap kemandirian belajar, pemerintah dalam peraturan menteri nomor 41 tahun 2007 menjelaskan bahwa sikap kemandirian belajar suatu sikap yang dimiliki individu untuk belajar dengan inisiatif sendiri dalam upaya menginternalisasi pengetahuan tanpa tergantung atau mendapat bimbingan langsung dari orang lain. Lebih lanjut mengenai sikap kemandirian belajar. Listyani (2008) menjelaskan bahwa terdapat enam buah indikator sikap kemandirian belajar, yaitu : (1) Ketidaktergantungan terhadap orang lain, (2) Memiliki kepercayaan diri, (3) Berperilaku disiplin, (4) Memiliki rasa tanggung jawab, (5) Berperilaku berdasarkan inisiatif sendiri, dan (6) Melakukan kontrol diri (Nasution, 2018).

Aksioma yang tak terbantahkan adalah bahwa pendidikan merupakan pilar bangsa. Setiap bangsa sangat menaruh harapan terhadap dunia pendidikan. Dari pendidikan inilah masa depan suatu bangsa dikontruksi dalam landasan yang kuat. Sebuah landasan yang mampu memandirikan anak bangsa dengan berbagai potensi yang dimilikinya.1 Undangundang Nomor 20 Tahun 2003 tentang Sistem Pendidikan Nasional menyebutkan bahwa Pendidikan adalah usaha sadar dan terencana untuk mewujudkan suasana belajar dan proses pembelajaran agar peserta didik secara aktif mengembangkan potensi dirinya untuk memiliki kekuatan spiritual keagamaan, pengendalian diri, kepribadian, kecerdasan, akhlak mulia, serta keterampilan yang diperlukan dirinya, masyarakat bangsa dan negara (pasal 1, butir 1). Pendidikan juga dapat diartikan sebagai proses pengubahan sikap dan tingkah laku seseorang atau sekelompok orang dalam usaha mendewasakan manusia melalui pengajaran dan latihan. Proses ini, dalam terminologi Arab, dikenal dengan istilah Tarbiyah yang secara keseluruhan menghimpun kegiatan yang terdapat dalam pendidikan, yaitu membina, memelihara, mengajarkan, menyucikan $\mathrm{j}$ iwa dan mengingatkan manusia terhadap hal-hal yang baik (Jalil, 2012).

Pendidikan lebih dari sekedar pengajaran, yang dapat dikatakan sebagai suatu proses transfer ilmu, transformasi nilai, dan pembentukan kepribadian dengan segala aspek yang dicakupnya. Dengan demikian pengajaran lebih berorientasi pada pembentukan spesialis atau bidangbidang tertentu, oleh karena itu perhatian dan minatnya lebih bersifat teknis. Pendidikan merupakan suatu proses yang diperlukan untuk mendapatkan keseimbangan dan kesempurnaan dalam perkembangan individu maupun masyarakat. Penekanan pendidikan dibanding dengan pengajaran terletak pada pembentukan kesadaran dan kepribadian individu atau masyarakat di samping transfer ilmu dan keahlian. Dengan proses semacam ini suatu bangsa atau negara dapat mewariskan nilai-nilai keagamaan, kebudayaan, pemikiran dan keahlian kepada generasi berikutnya, sehingga mereka betul-betul siap menyongsong masa depan kehidupan bangsa dan negara yang lebih cerah. Pendidikan juga merupakan sebuah aktifitas yang memiliki maksud atau tujuan tertentu yang diarahkan untuk mengembangkan potensi yang dimiliki manusia baik sebagai manusia ataupun sebagai masyarakat dengan sepenuhnya (Nurkholis, 2013).

Penyelenggaraan penguatan pendidikan karakter pada satuan pendidikan formal saat ini sangatlah diperlukan, hal ini dikarenakan anak usia sekolah merupakan aset bangsa dalam 
mewujudkan cita-cita bangsa yang berbudaya dan memiliki semangat kebangsaan, peduli sosial serta cinta tanah air. Hal ini sejalan dengan peraturan presiden (perpres No. 87 Tahun 2017 tentang penguatan pendidikan karakter).

Dalam Undang-undang (UU) No.20, tahun 2003 tentang Sistem Pendidikan Nasional pasal 3 dinyatakan bahwa Pendidikan nasional berfungsi mengembangkan kemampuan dan membentuk watak serta peradaban bangsa yang bermartabat dalam rangka mencerdaskan kehidupan bangsa, bertujuan untuk berkembangnya potensi peserta didik agar menjadi manusia yang beriman dan bertaqwa kepada Tuhan Yang Maha Esa, berakhlak mulia, sehat, berilmu, cakap, kreatif, mandiri, dan menjadi warga Negara yang demokratis serta bertanggung jawab. Sehingga nanatinya mampu menjadi anak bangsa yang membanggakan. Sebab anak merupakan dambaan bagi setiap orang tua dan anak adalah bagian dari generasi sebagai salah satu dari sumber daya manusia yang merupakan potensi dan penerus cita-cita perjuangan bangsa. Sehubungan dengan ketetapan UUD dan UU tentang Sisdiknas serta tujuan pendidikan nasional yang telah di tetapkan oleh pemerintah bahwa pendidikan di masa yang akan datang ini harus memiliki mutu dan berkualitas dibanding dengan pelaksanaan pendidikan yang telah berlangsung saat sekarang ini. Maka dari pada itu perlu ditegaskan bahwa Keputusan Presiden RI No 1 Tahun 2010 setiap jenjang pendidikan di Indonesia harus melaksanakan pendidikan karakter (Citra, 2012).

Di Indonesia pelaksanaan pendidikan karakter saat ini memang dirasakan mendesak. Gambaran situasi masyarakat bahkan situasi dunia pendidikan di Indonesia menjadi motivasi pokok (mainstreaming) implementasi pendidikan karakter di Indonesia. Pendidikan karakter di Indonesia dirasakan amat perlu pengembangannya bila mengingat makin meningkatnya tawuran antar pelajar, serta bentuk-bentuk kenakalan remaja lainnya terutama di kota-kota besar, pemerasan/kekerasan (bullying), kecenderungan dominasi senior terhadap yunior, penggunaan narkoba, dan lain-lain. (Muchlas Samani dan Hariyanto, 2011: 2). Menurut Garin Nugroho yang dikutip oleh Masnur Muslich, mengatakan bahwa sampai saat ini dunia pendidikan di Indonesia dinilai belum mendorong pembangunan karakter bangsa. Hal ini disebabkan oleh ukuran-ukuran dalam pendidikan tidak dikembalikan pada karakter peserta didik, tapi dikembalikan pada pasar. "Pendidikan nasional belum mampu mencerahkan bangsa ini. Pendidikan kita kehilangan nilai-nilai luhur itu". Lebih lanjut ia mengemukakan bahwa pendidikan karakter akan hancur dan akan menghilangkan aspek-aspek manusia dan kemanusiaan, karena kehilangan karakter itu sendiri”, ucapnya. (Masnur Muslich, 2013: 1-2) (Zulhijrah, 2015).

Prioritas pembangunan nasional sebagaimana yang dituangkan dalam Rencana Pembangunan Jangka Panjang (RPJP) Nasional Tahun 2005 - 2025 (UU No. 17 Tahun 2007) antara lain adalah dalam mewujudkan masyarakat yang berakhlak mulia, bermoral, beretika, berbudaya, dan beradab berdasarkan falsafah Pancasila". Salah satu upaya untuk merealisasikannya adalah dengan cara memperkuat jati diri dan karakter bangsa melalui pendidikan. Upaya ini bertujuan untuk membentuk dan membangun manusia Indonesia yang bertaqwa kepada Tuhan Yang Maha Esa, mematuhi aturan hukum, memelihara kerukunan internal dan antar umat beragama, melaksanakan interaksi antarbudaya, mengembangkan modal sosial, menerapkan nilai-nilai luhur budaya bangsa, dan memiliki kebanggaan sebagai bangsa Indonesia dalam rangka memantapkan landasan spiritual, moral, dan etika pembangunan bangsa. Pendidikan nasional berfungsi mengembangkan kemampuan dan membentuk watak serta peradaban bangsa yang bermartabat dalam rangka mencerdaskan kehidupan bangsa, yang bertujuan untuk berkembangnya potensi peserta didik agar menjadi manusia yang beriman dan bertakwa kepada Tuhan Yang Maha Esa, berakhlak mulia, sehat, berilmu, cakap, kreatif, mandiri, dan menjadi warga negara yang demokratis serta bertanggung jawab.Pendidikan merupakan bagian penting dari kehidupan manusia yang tak pernah bisa ditinggalkan. Pendidikan bukanlah proses yang diorganisasi secara teratur, terencana, dan menggunakan metode-metode yang dipelajari serta berdasarkan aturan-aturan yang telah disepakati mekanisme penyelenggaraan oleh suatu komunitas suatu masyarakat (Negara), melainkan lebih merupakan bagian dari kehidupan yang memang telah berjalan sejak manusia itu ada.Pendidikan bisa dianggap sebagai proses yang terjadi secara sengaja, direncanakan, didesain, dan diorganisasi berdasarkan aturan yang berlaku terutama perundang-undangan yang kesepakatan masyarakat.Pendidikan sebagai sebuah kegiatan dan proses aktivitas yang disengaja merupakan gejala masyarakat ketika sudah mulai disadari pentingnya upaya untuk membentuk, mengarahkan, dan mengatur manusia sebagaimana dicita-citakan masyarakat (Omeri, 2015). 
Penyelenggaraan penguatan pendidikan karakter bertujuan untuk menanamkan nilai-nilai pembentukan karakter bangsa secara masif dan efektif melalui lembaga pendidikan dengan prioritas nilai-nilai tertentu yang akan menjadi fokus pembelajaran, pemahaman, pengertian, dan praktik. Dengan demikian, pendidikan karakter bangsa sungguh dapat mengubah perilaku, cara berpikir, dan cara bertindak seluruh bangsa Indonesia menjadi lebih baik dan berintegritas. Penguatan Pendidikan karakter dimulai dari Pendidikan Anak Usia Dini (PAUD), dilanjutkan dengan prioritas pada jenjang pendidikan dasar, yaitu Sekolah Dasar dan Sekolah Menengah Pertama. Gerakan PPK pada usia dini dan jenjang pendidikan dasar ini akan diintegrasikan dengan prioritas nilai-nilai dalam GNRM sehingga terjadi perubahan yang masif dan serentak di seluruh Indonesia (Kementerian Pendidikan dan Kebudayaan Republik Indonesia, 2016:4). Penguatan Pendidikan Karakter (PPK) dilaksanakan dengan menerapkan nilai-nilai Pancasila dalam pendidikan karakter terutama meliputi nilai-nilai religius, jujur, toleran, disiplin, bekerja keras, kreatif, mandiri, demokratis, rasa ingin tahu, semangat kebangsaan, cinta tanah air, menghargai prestasi, komunikatif, cinta damai, gemar membaca, peduli lingkungan, peduli sosial, dan bertanggung jawab (Perpres Nomor 87 Tahun 2017 tentang Penguatan Pendidikan Karakter).

Menurut Wibowo (2016:11) dalam proses perkembangan dan pembentukannya, karakter seseorang dipengaruhi oleh dua faktor, yaitu faktor lingkungan (nurture) dan faktor bawaan (nature). Secara psikologis perilaku berkarakter merupakan perwujudan dari potensi Intelegence Queotient (IQ) yang dimiliki oleh seseorang. Konfigurasi karakter dalam konteks totalitas proses psikologis dan sosio-kultural pada akhirnya dapat dikelompokkan dalam empata kategori, yakni (1) olah hati (spiritual and emotional development); (2) olah pikir (intellectual development); (3) olah raga dan kinestetik (affective and creativity development). Keempat proses psiko-sosial ini secara holistik dan koheren saling terkait dan saling melengkapi dalam rangka pembentukan karakter dan perwujudan nilai-nilai luhur dalam diri seseorang.

Hasil observasi awal dan wawancara kepala sekolah peneliti mengenai penerapan penguatan pendidikan karakter sebagai implementasi kurikulum 2013 di SDN 1 Pulorejo yaitu dalam penanaman nilai karakter di SDN 1 Pulorejo diawali dari penetapan nilai-nilai karakter yang akan diterapkan di sekolah disepakati oleh seluruh warga sekolah, yaitu kepala sekolah, komite sekolah, guru, dan siswa. Nilai-nilai PPK dilaksanakan pada kegiatan ekstrakurikuler, yaitu pada kegiatan Pramuka; intrakurikuler dan kokulikuler, serta diterapkan dalam kebiasaan sehari-hari dalam merawat sarana dan prasarana sekolah. Selain itu nilai-nilai PPK diterapkan dalam kegiatan non-kurikuler dan pembiasaan PPK di sekolah seperti apel pagi, berjabat tangan dengan guru sebelum masuk kelas, berdoa bersama, membaca asmaul husna, menyanyikan lagu Indonesia Raya, membaca teks pancasila, dan literasi selama 15 menit. Kegiatan PPK terlihat pada pengintegrasian kurikulum, yaitu pada awal pembelajaran dan pada RPP. Hal ini menandakan bahwa sekolah sudah menanamkan nilai-nilai karakter.

Berdasarkan paparan di atas, beberapa keunikan itu membawa peneliti untuk melakukan penelitian di SDN 1 Pulorejo yaitu melakukan analisis yang berkaitan tentang penerapan penguatan pendidikan karakter sebagai implementasi pelaksanaan kurikulum 2013. Dari penelitian ini sekolah sudah melaksanakan Penguatan Pendidikan Karakter, akan tetapi sekolah belum mengetahui prinsip-prinsip penguatan pendidikan karakter yang harus diterapkan dalam pelaksanaan PPK di sekolah dan sekolah tidak mengetahui seberapa besar keberhasilan pelaksanaan PPK di sekolah. Sehingga penelitian ini sangat penting dilakukan untuk membantu sekolah untuk mengetahui prinsip-prinsip yang belum terlaksana disekolahan dan besar pelaksanaan PPK yang telah terlaksana di sekolah. Selain itu untuk memberikan masukan kepada sekolah untuk menambahkan prinsip-prinsip PPK yang belum terlaksana di sekolah.

Penelitian ini bertujuan untuk mengetahui penerapan penguatan pendidikan karakter sebagai implementasi kurikulum 2013 di SDN 1 Pulorejo.

\section{Metode}

Penelitian ini menggunakan pendekatan kualitatif, dengan rancangan penelitian yang digunakan adalah studi kasus. Teknik pengumpulan data diperoleh melalui wawancara mendalam, pengamat sebagai partisipasipan dan dokumentasi. Penelitian dilaksanakan dengan mengumpulkan data terlebih dahulu dari lapangan dimana tempat penelitiannya yaitu SDN 1 Pulorejo. Data penelitian yang telah didapatkan melalui beberapa teknik pengumpulan tadi kemudian dilakukan analisis dengan cara mereduksi data sesuai dengan kebutuhan dari fokus penelitian. Data yang telah direduksi kemudian disajikan dan ditarik kesimpulannya. Informan 
kunci dalam penelitian ini adalah kepala sekolah, sedangkan data lain yang mendukung didapatkan melalui informan tambahan yaitu guru, dan peserta didik. Pengecekan keabsahan data dilakukan peneliti untuk mempertanggung jawabkan kebenaran dari data yang telah didapatkan. Keabsahan data temuan dilakukan dengan tiga cara, yaitu triangulasi sumber, triangulasi teknik, dan triangulasi waktu.

\section{Hasil dan Pembahasan}

Menurut Kemendikbud (2016:14) strategi penguatan pendidikan karakter dilakukan melalui tiga basis utama pendekatan pendidikan karakter, antara lain sebagai berikut:

\section{Strategi penguatan pendidikan karakter berbasis kelas}

Strategi penguatan pendidikan karakter berbasis kelas dilakukan melalui proses Kegiatan Belajar-Mengajar (KBM) di dalam kelas. Penguatan pendidikan karakter dalam kegiatan belajar di dalam kelas bisa berupa pemilihan model pembelajaran tematik (ada alokasi waktu khusus untuk mengajarkan nilai-nilai tertentu), nontematik (terintegrasi dengan materi pembelajaran dalam kurikulum), dan non-instruksional (manajemen kelas dan organisasi fisik lingkungan kelas).

Berdasarkan penelitian yang peneliti lakukan di SDN 1 Pulorejo pendidik mengitegrasikan isi kurikulum untuk memperkuat pembentukan karakter melalui pembelajaran yang tampak dalam RPP, memberikan penekanan nilai-nilai inti pada mata pelajaran, mengajak peserta didik mendalami, mendiskusikan dan menyikapi persoalan moral yang terkandung di dalam materi ajarnya, menggunakan metode pembelajaran yang memperkuat pembentukan karakter, mempergunakan momen pengelolaan kelas untuk melatih peserta didik mempraktikkan nilai-nilai kebaikan.

\section{Strategi penguatan pendidikan karakter berbasis kultur sekolah}

Strategi penguatan pendidikan karakter berbasis kultur sekolah dilakukan melalui kegiatankokurikuler, ekstrakurikuler, dan pengembangan manajemen pengelolaan lembaga pendidikan (tata kelola sekolah, tata peraturan sekolah, norma-norma, regulasi pendidikan) yang mendukung pembentukan karakter peserta didik sebagai pembelajar.

SDN 1 Pulorejo memiliki program pembiasaan, diantaranya apel pagi, berjabat tangan dengan guru sebelum masuk kelas, berdoa bersama sebelum dan sesudah pembelajaran, membaca asmaul husna, menyanyikan lagu Indonesia Raya, membaca teks pancasila, dan literasi selama 15 menit. Sekolah mengajak peserta didik untuk berempati pada orang yang sedang sakit dan kesusahan melalui semngat gotong royong berupa iuran sukarela, dan sumbangan.sekolah melatih peserta didik untuk memperhatikan kelompok-kelompok masyarakat yang kurang beruntung, terkena bencana berupa penggalangan dana untuk korban bencana alam. Pendidik memberikan keteladanan moral dalam perkataan dan perbuatan.

\section{Strategi penguatan pendidikan karakter berbasis komunitas}

Strategi penguatan pendidikan karakter berbasis komunitas dilakukan dengan melakukan kerjasama dengan komunitas-komunitas di luar lembaga pendidikan sebagai sumber-sumber pembelajaran, tempat berbagi pengalaman dan keterampilan yang memperkuat penumbuhan karakter peserta didik.

Hasil dari penelitian yang peneliti lakukan sekolah memiliki program bersama yang melibatkan seluruh anggota komunitas untuk melakukan kegiatan tertentu, yantu berupa gotong royong membersihkan sekolah, kelas dan lingkungan masyarakat sekitar. Tata peraturan sekolah dikomunikasikan dengan seluruh anggota sekolah. Sekolah mempergunakan metode komunikasi dengan orang tua melalui pertemuan orang tua, dan grup WA.

\section{A. Nilai-nilai PPK yang di Implementasikan di Sekolah Dasar}

Implementasi Berdasarkan hasil angket setiap kelas dapat disimpulkan bahwa secara keseluruhan di SDN 1 Pulorejo nilai-nilai PPK sudah dilaksanakan. Akan tetapi seluruh nilai-nilai PPK terlaksana secara maksimal, dikarenakan karakter setiap orang berbeda sejalan dengan Wibowo (2016:11) dalam proses perkembangan dan pembentukannya, karakter seseorang dipengaruhi oleh dua faktor, yaitu faktor lingkungan (nurture) dan faktor bawaan (nature). nilai PPK religius terlaksana sebesar $84,73 \%$, nasionalis $82,30 \%$, mandiri $68,94 \%$, gotong-royong $59,73 \%$, integritas $48,00 \%$. 
Dari hasil nilai PPK maka yang muncul adalah religius. Hal ini dikarenakan sekolah sudah menerapkan kegiatan pembiasaan setiap harinya, walaupun tidak memiliki sarana dan prasarana yang mendukung tetapi untuk membiasakan kegiatan solat berjamaah di mushola yang letaknya disebelah utara sekolah, berdoa sebelum memulai dan sesudah pembelajaran, membaca asmaul husna, dll. Hal ini sejalan dengan teori Hendarman (2016:11) bahwa religius adalah sikap yang mencerminkan iman terhadap Tuhan Yang Maha Esa yang diwujudkan dalam perilaku untuk melaksanakan ajaran agama dan kepercayaan yang dianutnya, mengharagai perbedaan agama, menjunjung tinggi sikap toleran terhadap pelaksanaan ibadah agama dan kepercayaan lain, hidup rukun dan damai dengan pemeluk agama lain. Sikap religius juga ditunjukkan dalam perilaku mencintai dan menjaga keutuhan alam. Dengan subnilai religius: subnilai menghargai keragaman: cinta damai, toleransi, menhargai perbedaan agama, teguh pendirian, percaya diri, kerjasama lintas agama, antibuli dan kekerasan, persahabatan, ketulusan, tidak memaksa kehendak, melindungi, yang kecil dan tersisih.

Nilai nasionalis terlihat pada kegiatan setiap pagi meliputi apel pagi, berjabat tangan dengan guru sebelum masuk ruang kelas, menyanyikan lagu wajib, dan membaca sila-sila pancasila. Namun yang perlu ditingkatkan adalah apresiasi budaya lokal. Hal ini sejalan dengan teori Hendarman (2016: 11) bahwa nasionalis (cinta bangsa) adalah sebuah sikap untuk mampu mengapresiasi kekayaan budaya bangsa sendiri (kebijaksanaan, keutamaan, tradisi, nilai-nilai, pola pikir, mentalitas, produk budaya) dan terbuka pada budaya lain, mampu mengapresiasi kekayaan budaya bangsa lain sehingga memperkuat jati diri bangsa Indonesia. Dengan subnilai nasionalis antara lain: apresiasi budaya bangsa sendiri, menjaga kekayaan budaya bangsa, rela berkorban, cinta tanah air, menjaga lingkungan, taat hukum, disiplin, menghormati keragaman budaya, suku, dan agama.

Nilai mandiri terlihat pada kemampuan siswa dalam mengerjakan soal sesuai sendiri, apabila dalam mengerjakan soal mengalami kesulitan dalam menemukan jawaban siswa akan mencari solusi dengan sumber buku lain, dan tidak berhenti begitu saja apabila tidak bisa mengerjakan soal. siswa berani ikut lomba pesta siaga walaupun tidak dapat juara. Hal ini sejalan dengan teori Hendarman (2016: 11) bahwa mandiri merupakan sikap dan perilaku tidak bergantung pada orang tua lain dan mempergunakan segala tenaga, pikiran, waktu untuk merealisasikan harapan, mimpi dan cita-cita. Dengan subnilai kemandirian: etos kerja (kerja keras), tahan banting, daya juang, profesionalisme, kreatif, keberanian, dan menjadi pembelajar sepanjang hayat.

Nilai gotong royong terlihat ketika siswa yang menanyakan materi kepada guru tentang materi yang akan diajarkan lusa, berani untuk bertanya kepada guru ketika tidak paham dengan materi yang diajarkan oleh guru, memberikan tepuk tangan ketika ada teman yang mendapat nilai baik, memberika pendapat ketika kerja kelompok dikelas, tidak marah ketika guru menasehati apabila siswa melakukan kesalahan. Hal ini sejalan dengan teori Hendarman (2016:11) bahwa gotong-royong adalah kemampuan untuk bekerjasama satu sama lain dalam rangka memperjuangkan kebaikan bersama bagi masyarakat luas, terutama bagi mereka yang sangat membutuhkan perhatian karena miskin, tersingkir, dan terabaikan di dalam masyarakat. Dengan subnilai gotong royong: mampu bekerjasama dengan banyak pihak dan inklusif, menyelesaikan persoalan, memiliki sikap terbuka, mau menerima masukan dan kritik, memiliki komitmen atas keputusan bersama, musyawarah mufakat, tolong-menolong, solidaritas, empati.

Nilai-nilai integritas terlihat ketika siswa tidak mengerjakan PR di sekolah, tidak mengganggu teman ketika mereka sedang mengerjakan tugas, berhasil menyelesaikan tugas yang diberikan guru tepat waktu, tidak membuat gaduh di dalam kelas, tidak diam ketika belum paham dengan pembelajaran, mendengarkan ketika guru menjelaskan, tidak lupa mengerjakan tugas dari guru, dan tidak sering berbohong kepada orang tua. Hal ini sejalan dengan teori Hendarman (2016:11) bahwa integritas adalah kemampuan individu untuk menyelesaikan pemikiran, perkataan dan perbuatan yang mereprentasikan perilaku bermoral yang kebenarannya dapat dipertanggung jawabkan secara rasional. Dengan subnilai integritas adalah kejujuran, cinta pada kebenaran, setia, komitmen moral, tanggung jawab, keteladanan.

Berdasarkan hasil analisis penerapan penguatan pendidikan karakter sebagai implementasi kurikulum 2013 di SDN 1 Pulorejo diketahui bahwa SDN 1 Pulorejo sudah mengimplementasi pendidikan karakter dalam kurikulum 2013. Hasil analisis ini berdasarkan sepuluh prinsip pelaksanaan PPK. Pendidikan karakter disekolahan ini diselenggarakan melalui pendidikan dan pembelajaran untuk dapat mencapai visi yang unggul dalam prestasi, cerdas terampil beriman, bertaqwa, berakhlak mulia, berkarakter bangsa dan berwawasan gender, dan sesuai dengan peraturan presiden No. 87 Tahun 2017 tentang penguatan pendidikan karakter bahwa penyelenggaraan penguatan pendidikan karakter pada satuan pendidikan formal saat ini 
sangatlah diperlukan, hal ini dikarenakan anak usia sekolah merupakan aset bangsa dalam mewujudkan cita-cita bangsa yang berbudaya dan memiliki semangat kebangsaan, peduli sosial serta cinta tanah air.

\section{B. Evaluasi Pelaksanaan PPK}

Evaluasi PPK berdasarkan prinsip-prinsip PPK nilai-nilai moral universal ditunjukkan dalam indikator angka skor sebesar 3,33. Pendekatan Integral 4, pendekatan menyeluruh 4, terukur dan objektif 4 , pelibatan publik 4, kearifan lokal 0 , ketrampilan abad 213,75 , revolusi mental 4, adil dan inklusif 3 , evaluasi program 2,25.

Pelaksanaan PPK di SDN 1 Pulorejo diterapkan pada tiga basis dengan jenis kegiatan yang berbeda-beda. Hal ini selaras dengan bentuk Implementasi yang dicanangkan oleh Hendarman (2016:14), implementasi PPK dapat dilakukan dengan 3 pendekatan utama yaitu berbasis kelas, berbasis budaya sekolah, dan berbasis masyarakat. Dimana memang ketiga hal ini memiliki poin-poin yang semestinya dilaksanakan oleh sekolah sebagai salah satu bentuk program penguatan pendidikan karakter. Dimana memang SDN 1 Pulorejo menerapkan kegiatan pembiasaan dalam rangka untuk penerapan PPK yang sesuai dengan Perpres No. 87 mengenai Penguatan Pendidikan Karakter pasal 6 ayat 1 bahwa inti dari ayat tersebut adalah menyebutkan penguatan pendidikan karakter diintegrasiikan ke dalam 3 aspek yakni intrakurikuler, kokurikuler dan ekstrakurikuler. Dimana memang dalam ketiga hal tersebut juga didukung dengan kegiatan rutin yang dilakukan di lingkungan sekolah maupun di kelas.

Berdasarkan strategi penguatan pendidikan karakter yang terdiri dari tiga basis utama pendekatan pendidikan karakter yaitu strategi penguatan pendidikan karakter berbasis kelas ditunjukkan dalam indikator angka skor sebesar 4, berbasis kultur sekolah 4, berbasis komunitas sebesar 4 .

\section{Simpulan dan Saran}

Penerapan pendidikan karakter diselenggarakan di SDN 1 Pulorejo sudah terlaksana dengan baik dan sesuai dengan peraturan presiden No. 87 Tahun 2017 tentang penguatan pendidikan karakter bahwa penyelenggaraan penguatan pendidikan karakter pada satuan pendidikan formal saat ini sangatlah diperlukan, hal ini dikarenakan anak usia sekolah merupakan aset bangsa dalam mewujudkan cita-cita bangsa yang berbudaya dan memiliki semangat kebangsaan, peduli sosial serta cinta tanah air.

Berdasarkan prinsip-prinsip Penguatan Pendidikan Karakter nilai-nilai moral universal ditunjukkan dalam indikator angka skor sebesar 3,33. Pendekatan Integral 4, pendekatan menyeluruh 4 , terukur dan objektif 4 , pelibatan publik 4 , kearifan lokal 0 , ketrampilan abad 21 3,75 , revolusi mental 4 , adil dan inklusif 3 , evaluasi program 2,25. Dilihat dari strategi penguatan pendidikan karakter yang terdiri dari tiga basis utama pendekatan pendidikan karakter yaitu strategi penguatan pendidikan karakter berbasis kelas ditunjukkan dalam indikator angka skor sebesar 4, berbasis kultur sekolah 4, berbasis komunitas sebesar 4 .

Peneliti menyarankan perlu adanya budaya lokal, dan mengevaluasi nilai-nilai PKK melalui dibentuknya instrumen supervisi yang dikaitkan dengan pelaksanaan PPK.

\section{Daftar Pustaka}

Citra, Yulia. 2012. Pelaksanaan Pendidikan Karakter Dalam Pembelajaran . Jurnal IImiah Pendidikan Khusus . Volume 1 Nomor 1 Januari 2012

Hendarman, dkk. 2017.Konsep dan Pedoman Penguatan Pendidikan Karakter. Jakarta. Kemendikbud.

Jalil, Abdul. 2012. Karakter Pendidikan untuk Membentuk Pendidikan Karakter . Jurnal Pendidikan Islam Vol. 6, Nomor 2, Oktober 2012

Kemendikbud. 2016. Kajian dan Pedoman Penguatan Pendidikan Karakter. Jakarta. Kementerian Pendidikan dan Kebudayaan Republik Indonesia.

Kemendikbud. 2016. Modul Pelatihan Penguatan Pendidikan Karakter Bagi Komite Sekolah. Jakarta. Kementerian Pendidikan dan Kebudayaan Republik Indonesia. 
IVCEJ, Vol 2 No 2, Tahun 2019

Kemendikbud. 2016. Panduan Implementasi Penguatan Pendidikan Karakter Tingkat Sekolah Dasar dan Sekolah Menengah Pertama "Senang Belajar di Rumah Kedua". Jakarta. Kementerian Pendidikan dan Kebudayaan Republik Indonesia.

Kemendikbud. 2016. Panduan Penilaian Penguatan Pendidikn Karakter Tingkat Sekolah Dasar dan Sekolah Menengah Pertama. Jakarta. Kementerian Pendidikan dan Kebudayaan Republik Indonesia.

Nurkholis. 2013. Pendidikan Dalam Upaya Memajukan Teknologi . Jurnal Kependidikan, Vol. 1 No. 1 Nopember 2013

Nasution, Toni. 2015. Membangun Kemandirian Siswa Melalui Pendidikan Karakter . Jurnal ljtimaiyah Vol.2 No.1 Januari-Juni 2018 Issn 2541-660x

Omeri, Nopan. 2015. Pentingnya Pendidikan Karakter Dalam Dunia Pendidikan . Jurnal Manajer Pendidikan, Volume 9, Nomor 3, Juli 2015, hlm. 464-468

Perpres 2017 No. 87 Pasal 3, Penguatan Pendidikan Karakter.

Wibowo, Agus. 2016. Management Pendidikan Karakter di Sekolah. Yogyakarta. Pustaka Pelajar.

Zulhijrah. 2015. Implementasi Pendidikan Karakter Di Sekolah .Jurnal Tadrib Vol. 1 No.1 Juni 2015 